\title{
Fizičnogeografsko vrednotenje podeželskega prostora za kmetijstvo in pozidavo
}

\author{
Maja Topole \\ Dr., Geografski inštitut Antona Melika, Znanstvenoraziskovalni center SAZU, \\ Gosposka 13, 1000 Ljubljana, Slovenija \\ e-mail: maja.topole@zrc-sazu.si
}

\section{Izvleček}

Članek predstavlja metodologijo vrednotenja podeželskega prostora z vidika kmetijstva in pozidave. Kriteriji primernosti površin za njive, vinograde, sadovnjake, travnike in pozidavo so fizičnogeografski dejavniki. Poudarek je na geografskem informacijskem sistemu, na kvantitativnih metodah in ponderiranju - oceni teže geoekoloških dejavnikov v primeru različnih tipov rabe tal.

Ključne besede: geografija podeželja, raba tal, kmetijsko vrednotenje prostora, vrednotenje prostora za pozidavo, regionalno planiranje, geografski informacijski sistem

\section{Evaluation of Space for Various Types of Land Use}

\begin{abstract}
The paper presents a method for evaluating rural space, especially for agriculture and built-up areas. The criteria of land suitability for arable surfaces, vineyards, orchards, meadows and built-up areas are selected geoecological factors. The stress is on Geographical Information System and on quantitative methods. The establishing the degree of significance of geo-factors in cases of different types of land use is of special importance.
\end{abstract}

Key words: 


\section{UVOD}

Referat predstavlja metodo, ki se ukvarja $\mathrm{z}$ vrednotenjem podeželskega prostora. V praksi je bila že uporabljena v okviru projekta Celostno urejanje podeželja in obnova vasi (CRPOV) in sicer v dveh primerih: v Šentruperski mikroregiji v občini Trebnje in v občini Moravče. Razvita je bila v skladu s prizadevanji za čim bolj celostno planiranje razvoja podeželja.

Metodo lahko uporabimo šele na določeni stopnji razvoja geografije in sorodnih strok, ko je za posamezno pokrajinsko enoto že izdelana večina osnovnih zemljevidov $\mathrm{v}$ večjem in srednje velikem merilu $(1: 10.000$ do $1: 50.000$, izjemoma $1: 100.000)$. Nepogrešljivi so:

1. digitalni model reliefa $100 \times 100 \mathrm{~m}$ (Geodetska uprava R Slovenije),

2. topografska karta $\vee M 1: 25.000$ (Geodetska uprava R Slovenije),

3. letalski posnetki v M $1: 17.500$ (Geodetska uprava R Slovenije),

4. geološka karta v M $1: 100.000$ (Geološki zavod Slovenije),

5. karta potresne nevarnosti (Agencija R Slovenije za okolje),

6. pedološka karta v M $1: 50.000$ (Katedra za pedologijo, prehrano rastlin in ekologijo Biotehniške fakultete v Ljubljani),

7. vegetacijska karta v M $1: 50.000$ (Biološki inštitut Jovana Hadžija ZRC SAZU, Ljubljana) in

8. karta osončenosti oz. kvaziglobalnega obsevanja (Geografski inštitut Antona Melika ZRC SAZU, Ljubljana).

9. Upoštevati moramo tudi razširjenost poplavnega sveta. Karte glavnih poplavnih območij v Sloveniji so na razpolago na Geografskem inštitutu Antona Melika ZRC SAZU, če pa gre za manjša, še neobdelana območja, smo se prisiljeni odpraviti na teren.

Ostale potrebne karte je mogoče izpeljati iz doslej naštetih virov.

Preučitev vseh zemljevidov omogoča temeljito poznavanje regionalne geografije posamezne enote in njeno regionalizacijo, to je členitev v mezo- in mikroregije. Šele, ko dodobra poznamo pokrajino, njeno zgradbo in zakonitosti prepletanja naravnih in družbenih dejavnikov, lahko vrednotimo zemljišča, to je: ugotavljamo primernost zemljišč za posamezne tipe kmetijske in druge rabe tal.

Kot osnovo uporabljamo digitalni model reliefa $100 \times 100 \mathrm{~m}$. Od velikosti obravnavane pokrajine je odvisno, ali se odločimo za velikost celice $25 \mathrm{x}$ 25 ali 50 x $50 \mathrm{~m}$. Večje posploševanje je primerno le za oblikovanje splošne slike o pokrajini. Ko imamo mrežo več deset tisoč kvadratkov oziroma celic, znotraj vsake od njih izvedemo številne izračune.

V prvi fazi preučevanja analiziramo poglavitne naravno- in družbenogeografske dejavnike. Tu gre za klasično fizično, družbeno in regionalno geo- 
grafijo. Zberemo obstoječe osnovne karte. Če karte, ki prikazujejo ploskovne pojave, niso $\mathrm{v}$ digitalni obliki, jih digitaliziramo. Najprej spoznavamo značilnosti površja. S pomočjo osnovne geološke karte $\mathrm{v}$ merilu $1: 100.000$ izdelamo litološko karto, na tej podlagi pa karto nosilnosti tal. Pri tej ločimo tri oziroma štiri razrede: 1. trde, kompaktne kamnine, ki so zelo dobro nosilne, 2. mehkejše, a večinoma kompaktne kamnine, ki so srednje nosilne, 3. sipko in nesprijeto kamninsko kamninsko podlago, ki ima slabo nosilnost, in 4. tla, ki zaradi polzenja ali vodnatosti niso nosilna (melišča, vodnate in vodne površine). Kriterij nosilnosti nas zanima samo pri vrednotenju tal z vidika pozidave. Če korelacijski koeficient pokaže, da ljudje pri gradnji svojih bivališč niso upoštevali značilnosti kamninske podlage, a karta seizmičnosti uvršča obravnavano regijo med območja $\mathrm{z}$ visoko in višjo stopnjo potresne ogroženosti, ponder določimo umetno. Iz litološke karte izpeljemo tudi karto tipov površja (1. destrukcijski rečno-denudacijski, 2. akumulacijski rečno-denudacijski, 3. apneniški kraški in 4. dolomitni kraški relief). $\mathrm{S}$ to karto in $\mathrm{s}$ karto tipov prsti je močno povezana karta talnih vodnih razmer, ki prikazuje: 1 . območja normalnega vodnega odtoka, 2 . območja $z$ relativno veliko sušnostjo ali vlažnostjo, 3. poplavna območja in 4. stalne vodne površine.

$\mathrm{S}$ pomočjo digitalnega modela reliefa izdelamo karto relativnih in karto absolutnih nadmorskih višin. Od namena je odvisno, kako široke razrede oblikujemo. Širina razredov je odvisna tudi od tipa pokrajine. V primeru gričevnato-hribovitega sveta se za potrebe regionalizacije navadno odločimo za stometrske višinske pasove, pri manjši razčlenjenosti pa za petdesetmetrske ali celo ožje pasove. Podobno dobimo s pomočjo digitalnega modela reliefa tudi karto naklonov. Tudi tu ohranimo osnovno obliko, kjer nakloni niso združeni $\mathrm{v}$ razrede, saj jih bomo kasneje večkrat pregrupirali. Za različne namene so nam namreč potrebne različne meje razredov (za ugotavljanje primernosti območij za strojno obdelavo ene, za ugotavljanje stopnje občutljivosti območij za erozijo druge meje...).

Zaradi potreb regionalizacije preučimo tudi vodovje - to je: skupno dolžino vodotokov, njihovo gostoto, tip (stalni, občasni vodotoki, suhe doline), vodnatost - pretok in rečni režim, pa tudi poplavne razmere. Ločimo: 1. območja, ki so varna pred poplavami, 2. območja izrednih poplav in 3. območja rednih poplav).

Med podnebnimi dejavniki analiziramo temperature, padavine, ekspozicije, osončenost in razporeditev toplotnih pasov. Temperaturno in padavinsko sliko potrebujemo le za umestitev pokrajine v širše okolje, $v$ podnebno enoto. Zaradi majhnosti preučevane pokrajine znotraj nje razlike $\mathrm{v}$ količini padavin ne pridejo do izraza, ali se le komaj kažejo. Za nas sta pomembni predvsem karta osončenosti in karta toplotnih pasov. Kažeta namreč mezoin mikroklimatske razlike. Različna letna količina prejete toplotne energije 
pomembno odloča o primernosti površin za različno rabo tal. Letno prejeto energijo kvaziglobalnega sončnega obsevanja merimo $v \mathrm{MJ} / \mathrm{m}^{2}$. Ločimo razrede širine $100 \mathrm{MJ} / \mathrm{m}^{2}$. Glede na pripadnost toplotnemu pasu pa omejimo termalni, inverzijski in višinski pas. Ker navadno nimamo na razpolago več temperaturnih postaj, ki bi zaznale meje posameznih toplotnih pasov, jih omejimo posredno. To najlažje storimo v vinogradniški pokrajini, kjer sprejmemo spodnjo mejo vinogradov kot mejo med inverzijskim in termalnim pasom, njihovo zgornjo mejo pa kot mejo med termalnim in višinskim pasom. V pokrajini, kjer ni vinogradov, se moramo, kljub temu, da inverzijska ploskev ni vodoravna, zadovoljiti $\mathrm{z}$ neko izohipso, ki jo določimo s pomočjo razširjenosti ene od občutljivih vrst sadnega drevja.

Eden pomembnih kriterijev pri odločanju za neko rabo je prst. Ugotavljamo tipe prsti in njihovo razporeditev. Najbolj bi nam koristili karta rodovitnosti prsti in karta občutljivosti prsti za erozijo, vendar teh večinoma nimamo na razpolago. V primeru območij, kjer je erozija velik problem, jo lahko približno ocenimo s pomočjo Wischmeier-Smithove enačbe (Morgan, 1980, Goldman, 1986), ki upošteva erozivnost ali razdiralno moč dežja, erodibilnost prsti, topografski faktor, pokritost prsti z rastlinstvom in človeški dejavnik, to je način obdelave.

Naslednji fizičnogeografski dejavnik, ki nas zanima, je rastlinstvo. Ugotovimo pripadnost rastlinskemu zemljepisnemu območju in različnim gozdnim združbam. Najprej nas zanimajo gozdne in negozdne površine, potem pa še vrsta rastlinske odeje, saj pomembno vpliva na občutljivost prsti za erozijo.

Pokrajinska prvina, ki odseva fizično- in družbenogeografske dejavnike, je raba tal. Obstoječo rabo tal še posebej skrbno preučimo, saj bomo na tej podlagi ugotavljali težo posameznega naravnega dejavnika $\mathrm{v}$ primeru različnih tipov rabe tal. $Z$ ažurnim stanjem obstoječe rabe tal se seznanimo s pomočjo najnovejših letalskih posnetkov v merilu $1: \mathbf{1 7 . 5 0 0}$. Ciklično aerosnemanje opravlja Geodetski zavod Republike Slovenije od leta 1975. Sprejet je triletni cikel, kar pomeni, da je celotna Slovenija posneta v treh letih. S pomočjo stereoskopa in letalskih posnetkov lahko dobro spoznamo geomorfološke značilnosti površja. $Z$ njih razberemo tudi tipe rabe tal in jih prenesemo na topografsko karto $v$ merilu $1: 25.000$. Sledi digitaliziranje. V prepoznavanju rabe tal z letalskih posnetkov se sicer sčasoma zelo izurimo, a kljub temu je potrebno kontrolno preverjanje na terenu. Rabo tal za manjša območja lahko posnamemo tudi $z$ digitalnih ortofoto načrtov (merilo 1:5000 - DOF5). Slovenija je bila $\mathrm{z}$ njimi prvič $\mathrm{v}$ celoti prekrita leta 2001 .

Med tipi rabe tal ločimo pozidane površine, vinograde, njive, sadovnjake, travnike, površine $v$ zaraščanju, gozd, nerodovitne in vodne površine. Območje vrednotimo samo za potrebe pozidave in kmetijstva, to je za orne površine, sadovnjake, travnike in vinograde, če ti obstajajo. V primeru 
občine Moravče smo ugotavljali primernost površin za pozidavo, njive, sadovnjake in travnike.

Med družbenogeografskimi dejavniki upoštevamo prebivalstvo in naselja. Izdelamo karte naravnega, selitvenega in skupnega gibanja prebivalcev, karte razporeditve in gostote prebivalstva, karte spolne, starostne in po potrebi druge sestave prebivalstva. Posebej nas zanima delež kmečkega prebivalstva in struktura prebivalstva po dejavnosti. Preučimo razporeditev in gostoto naselij, njihovo velikost, lego in tip. Vsi ti družbenogeografski pokazatelji nam služijo pri regionalizaciji.

Ugotavljamo medsebojno odvisnost in součinkovanje naravnih in družbenih dejavnikov in odkrivamo zakonitosti pojavljanja posameznega tipa rabe tal. Pri tem si pomagamo z računanjem indeksov koncentracije.

Prvo fazo preučevanja sklenemo z regionalizacijo, ki je prva sinteza. Izvedemo jo s prekrivanjem gornjih kart.

Druga faza je nadgradnja prve in glavni cilj geografskega preučevanja. $\mathrm{Tu}$ gre za vrednotenje zemljišč za različne tipe rabe tal oziroma za predlog najprimernejše rabe tal.

V primeru moravške občine smo kot glavne kriterije, s pomočjo katerih smo vrednotili geoekološke razmere za kmetijstvo (za orne površine, sadjarstvo, travništvo) ter za pozidavo, izbrali: nadmorsko višino, naklone, višinske razlike, nosilnost tal ali posredno litološko osnovo, osončenost, toplotne pasove, tip prsti, način vodnega odtoka oziroma vodne razmere $\mathrm{v}$ prsti in poplavne razmere.

Oglejmo si primer nadmorskih višin kot enega fizičnogeografskih kriterijev za ugotavljanje primernosti območij za pozidavo. V prvi fazi imamo pri posamezni karti, ki prikazuje nadmorske višine, poljubno, navadno veliko število razredov. Karta nadmorskih višin v občini Moravče loči 13 petdesetmetrskih pasov. Ko v drugi fazi isti fizičnogeografski dejavnik uporabimo kot kriterij primernosti, razrede večkrat spremenimo. Najprej izračunamo frekvence, ki povedo, koliko pozidanih površin odpade na določen višinski razred (ki je čim ožji) in nato kumulativno frekvenco, ki jo potrebujemo, da potegnemo meje med štirimi kakovostnimi razredi primernosti. Prvi kakovostni razred pomenijo nadmorske višine, znotraj katerih najdemo $68 \%$ vseh pozidanih površin, drugi kakovostni razred nadmorske višine, na katerih je 27 \% vseh pozidanih površin in tretji kakovostni razred tiste nadmorske višine, kjer je le še $5 \%$ vseh pozidanih površin. Te meje so v skladu z normalno porazdelitvijo v statistiki. Četrti kakovostni razred je najneugodnejši in pomeni, da v njegovih mejah ne najdemo več nobenih pozidanih površin, ker dejavnik pozidavo absolutno izključuje. Nadmorske višine v moravški občini niso tolikšne, da bi izključevale možnost pozidave. Četrtega kakovostnega razreda v tem primeru ni, obstaja pa v primeru kake regije, ki vključuje tudi visokogorje. 
Nadmorske višine so močnejši omejitveni dejavnik pri kaki drugi rabi, na primer pri vinogradih. Iste nadmorske višine torej lahko pomenijo 3. kakovostni razred $\mathrm{z}$ vidika pozidave, 4. razred pa $\mathrm{z}$ vidika vinogradništva. Območja rednih poplav pomenijo $\mathrm{z}$ vidika pozidave 4 . kakovostni razred, $\mathrm{z}$ vidika ornih površin pa tretjega.

Postopek ni vedno enostaven. Delež pozidanih površin navadno pravilno pada $\mathrm{z}$ rastjo nadmorske višine, a to ni pravilo. V primeru sadnega drevja, še bolj pa vinogradov, so zaradi pojava toplotnega obrata najprimernejše neke srednje višine, manj so primerne višine $\mathrm{v}$ dnu dolin oziroma kotlin, najmanj pa $\mathrm{v}$ višinskem pasu, na primer nad nadmorsko višino 500 ali $600 \mathrm{~m}$. Zato je tu za posamezne razrede potrebno izračunati indekse koncentracije, razrede rangirati po pomenu in šele potem računati kumulativne frekvence. Tak je postopek omejevanja kakovostnih razredov tudi v primerih, kjer ne gre za numerične znake kot pri nadmorskih višinah, ampak za atributivne znake, kot so tip prsti, poplavna območja, toplotni pasovi.

Najpomembnejša dela druge faze sta:

1. omejitev kakovostnih razredov za vsak posamezen tip rabe posebej in

2. določanje ponderja, to je teže posameznega dejavnika za vsak tip rabe tal posebej.

Slika 1: Upoštevani geoekološki dejavniki in njihovi ponderji pri različnih tipih rabe tal

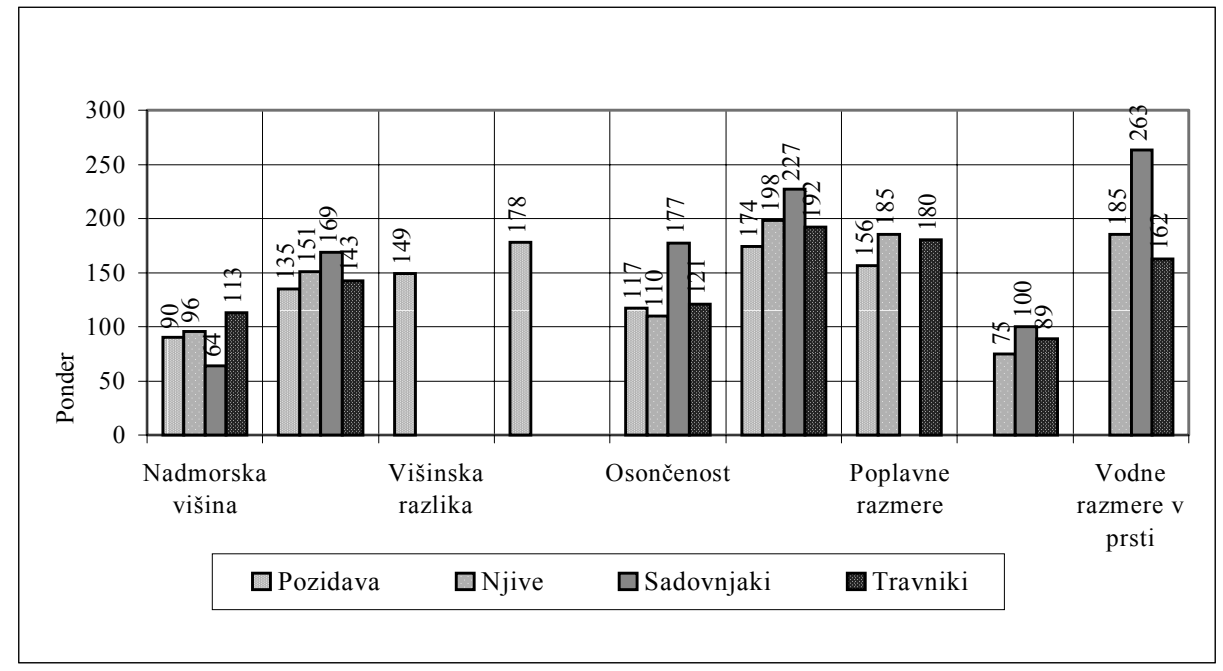


Ponderje smo izračunali s pomočjo korelacijskih koeficientov (Pearson). Kažejo stopnjo povezanosti oziroma odvisnost nekega tipa rabe od določenega fizičnogeografskega dejavnika. Zaradi lažje primerljivosti izračunamo ponderje tako, da je vsota ponderjev vseh upoštevanih dejavnikov pri enem tipu rabe tal enaka 1000.

Povezanost posameznih tipov rabe tal $\mathrm{z}$ osnovnimi fizičnogeografskimi prvinami (korelacijske koeficiente) prikazuje naslednja večdelna preglednica. Iz nje so razvidni tudi na korelacijskih koeficientih temelječi ponderji, način točkovanja po kakovostnih razredih upoštevanih geoekoloških dejavnikov za vsak posamezen tip rabe tal posebej in meje kakovostnih razredov.

$\mathrm{V}$ primeru moravške občine smo meje med štirimi kakovostnimi razredi določili takole.

Po nadmorski višini smo površinsko enoto uvrstili v prvi kakovostni razred, če leži glede na pozidavo do $440 \mathrm{~m}$, orne površine do $420 \mathrm{~m}$, sadjarstvo 430 do $560 \mathrm{~m}$ in za travništvo do $440 \mathrm{~m}$ visoko. V drugi razred spada, če leži z vidika pozidave 440 do $620 \mathrm{~m}$ visoko, ornih površin 420 do $520 \mathrm{~m}$, sadjarstva 350 do 430 ali 560 do $640 \mathrm{~m}$ visoko in z vidika travništva 440 do $650 \mathrm{~m}$ visoko. Tretji kakovostni razred pomenijo pri pozidavi višine nad $620 \mathrm{~m}$, pri ornih površinah nad $520 \mathrm{~m}$, sadjarstvu pod 350 ali 640 do $800 \mathrm{~m}$ visoko. Četrti kakovostni razred smo v obravnavani regiji, ki ne presega $880 \mathrm{~m}$, uvedli le pri sadovnjakih (nad $800 \mathrm{~m}$ ). Korelacijski koeficienti med nadmorsko višino in rabo tal kažejo, da medsebojne povezave niso zelo močne. To pomeni, da je višinski razpon, kjer se pojavlja posamezen tip rabe tal, dokaj širok. Še najmočnejša je povezanost med travniki in nadmorskimi višinami (0.5717). Sledijo pozidava (0.5021), njive $(0.4761)$ in sadovnjaki (0.2317).

Po naklonu se površinska enota uvršča v prvi kakovostni razred pri naklonu pod $11^{\circ}$ za pozidavo, pod $9^{\circ}$ za orne površine, pod $16^{\circ}$ za sadjarstvo in pod $12^{\circ}$ za travništvo. V drugem kakovostnem razredu je, če meri naklon 11$17^{\circ}$ (pozidava), $9-15^{\circ}$ (orne površine), $16-20^{\circ}$ (sadjarstvo) in $12-17^{\circ}$ (travništvo). Tretji kakovostni razred pomeni naklon 18 do $30^{\circ}$ za pozidavo, 16 do $30^{\circ}$ za orne površine, med 21 in $30^{\circ}$ za sadjarstvo, ter med 18 in $30^{\circ}$ za travništvo. Če meri naklon $30^{\circ}$ ali več, je enota $\mathrm{z}$ vidika vseh vrst rabe $\mathrm{v}$ četrtem razredu.

Korelacijski koeficienti, ki kažejo povezavo med nakloni in posameznimi tipi rabe tal, so zelo visoki. Od njih so najbolj odvisne pozidane površine (korelacija 0.7452$)$ in orne površine $(0.7407)$, sledijo pa travniki $(0.7196)$ in sadovnjaki (0.6055). Zanimivo je, da je naklon pri vseh tipih rabe tal pomembnejši kot nadmorska višina. 


\begin{tabular}{|c|c|c|c|c|}
\hline \multicolumn{5}{|c|}{ Korelacijski koeficienti, ponderji in število točk po upoštevanih geoekoloških dejav- } \\
\hline \multicolumn{5}{|c|}{ A) POZIDANE POVRŠINE } \\
\hline \multirow{2}{*}{$\begin{array}{l}\text { Geofaktor oz. geoeko- } \\
\text { loški dejavnik }\end{array}$} & \multirow{2}{*}{$\begin{array}{c}\text { Korel. koefici- } \\
\text { ent } \\
\mathbf{K}\end{array}$} & \multirow{2}{*}{$\begin{array}{c}\text { Ponder } \\
(\mathbf{P}=\mathrm{K} / \\
\Sigma \mathrm{A} \\
\mathrm{x} 1000)\end{array}$} & \multicolumn{2}{|c|}{$\begin{array}{c}1 \\
68 \% \text { primerkov }\end{array}$} \\
\hline & & & $\begin{array}{c}\text { Št. točk } \\
\mathbf{T}=\mathrm{P}\end{array}$ & Meje razreda \\
\hline 1. Nadmorska višina & 0,5 & 90 & 90 & $<440 \mathrm{~m}$ \\
\hline 2. Naklon & 0,75 & 135 & 135 & $<11^{\circ}$ \\
\hline 3. Višinska razlika & 0,83 & 149 & 149 & $<170 \mathrm{~m}$ \\
\hline 4. Nosilnost tal & 0,99 & 178 & 178 & najboljša \\
\hline 5. Osončenost & 0,65 & 117 & 117 & $>4100 \mathrm{MJ} / \mathrm{m}^{2}$ \\
\hline 6. Toplotni pas & 0,97 & 174 & 174 & termalni \\
\hline 7. Poplavne razmere & 0,87 & 156 & 156 & ni poplav \\
\hline Vsota A $(\Sigma \mathbf{A})$ & 5,11 & 1000 & 1000 & \\
\hline \multicolumn{5}{|c|}{ B) NJIVSKE POVRŠINE } \\
\hline \multirow{2}{*}{$\begin{array}{l}\text { Geofaktor oz. geoeko- } \\
\text { loški dejavnik }\end{array}$} & \multirow{2}{*}{$\begin{array}{l}\text { Korel. } \\
\text { koeficient } \\
\mathbf{K}\end{array}$} & \multirow{2}{*}{$\begin{array}{c}\text { Ponder } \\
(\mathbf{P}=\mathrm{K} / \\
\Sigma \mathrm{B} \\
\mathrm{x} 1000)\end{array}$} & \multicolumn{2}{|c|}{$\begin{array}{c}1 \\
68 \% \text { primerkov }\end{array}$} \\
\hline & & & $\begin{array}{c}\text { Št. točk } \\
\text { T=P }\end{array}$ & Meje razreda \\
\hline 1. Nadmorska višina & 0,47 & 96 & 96 & $<420 \mathrm{~m}$ \\
\hline 2. Naklon & 0,74 & 151 & 151 & $<9^{\circ}$ \\
\hline 3. Tip prsti & 0,37 & 75 & 75 & l \\
\hline 4. Vod. razmere v prsti & 0,91 & 185 & 185 & normalen odtok \\
\hline 5. Osončenost & 0,54 & 110 & 110 & $>4200 \mathrm{MJ} / \mathrm{m}^{2}$ \\
\hline 6. Toplotni pas & 0,97 & 198 & 198 & termalni \\
\hline 7. Poplavne razmere & 0,91 & 185 & 185 & ni poplav \\
\hline Vsota B $(\Sigma$ B $)$ & 4,91 & 1000 & 1000 & \\
\hline
\end{tabular}


Fizičnogeografsko vrednotenje podeželskega prostora za kmetijstvo in pozidavo

\begin{tabular}{|c|c|c|c|c|c|}
\hline \multicolumn{6}{|c|}{ nikih in po tipih rabe tal } \\
\hline \multicolumn{6}{|c|}{ Kakovostni razred } \\
\hline \multicolumn{2}{|c|}{$\begin{array}{c}\mathbf{2} \\
27 \% \text { primerkov } \\
\end{array}$} & \multicolumn{2}{|c|}{$\begin{array}{c}3 \\
5 \% \text { primerkov }\end{array}$} & \multicolumn{2}{|c|}{$\begin{array}{c}\mathbf{4} \\
\text { abs. onemogočena raba }\end{array}$} \\
\hline $\begin{array}{l}\text { Št. točk } \\
\mathbf{T}=2 / 3 \mathrm{P}\end{array}$ & Meje razreda & $\begin{array}{l}\text { Št. točk } \\
\mathbf{T}=1 / 3 \mathrm{P}\end{array}$ & Meje razreda & Št. točk & Meje razreda \\
\hline 60 & $440-620 \mathrm{~m}$ & 30 & $>620 \mathrm{~m}$ & -1000 & / \\
\hline 90 & $11-17^{\mathrm{o}}$ & 45 & $18-30^{\circ}$ & -1000 & $>30^{\circ}$ \\
\hline 100 & $170-300 \mathrm{~m}$ & 50 & $>300 \mathrm{~m}$ & -1000 & l \\
\hline 119 & srednja & 59 & slaba & -1000 & tla niso nosilna \\
\hline 78 & $4100-3600 \mathrm{MJ} / \mathrm{m}^{2}$ & 39 & $<3600 \mathrm{MJ} / \mathrm{m}^{2}$ & -1000 & l \\
\hline 116 & inverzijski & 58 & višinski & -1000 & / \\
\hline 104 & l & 52 & izredne poplave & -1000 & redne poplave \\
\hline 667 & & 333 & & -7000 & \\
\hline \multicolumn{6}{|c|}{ Kakovostni razred } \\
\hline \multicolumn{2}{|c|}{$\begin{array}{c}2 \\
27 \% \text { primerkov }\end{array}$} & \multicolumn{2}{|c|}{$\begin{array}{c}\mathbf{3} \\
5 \% \text { primerkov }\end{array}$} & \multicolumn{2}{|c|}{$\begin{array}{c}4 \\
\text { abs. onemogočena raba }\end{array}$} \\
\hline $\begin{array}{l}\text { Št. točk } \\
\mathbf{T}=2 / 3 \mathrm{P}\end{array}$ & Meje razreda & $\begin{array}{l}\text { Št. točk } \\
\mathbf{T}=1 / 3 \mathrm{P}\end{array}$ & Meje razreda & Št. točk & Meje razreda \\
\hline 64 & $420-520 \mathrm{~m}$ & 32 & $>520 \mathrm{~m}$ & -1000 & l \\
\hline 101 & $9-15^{\circ}$ & 50 & $16-30^{\circ}$ & -1000 & $>30^{\circ}$ \\
\hline 50 & $5,6,7,8,10,11$ & 25 & $1,2,3,4,9$ & -1000 & l \\
\hline 123 & sušno ali vlažno & 62 & poplavne vode & -1000 & stoječa voda \\
\hline 73 & $4200-3900 \mathrm{MJ} / \mathrm{m}^{2}$ & 37 & $3899-3100 \mathrm{MJ} / \mathrm{m}^{2}$ & -1000 & $<3100 \mathrm{MJ} / \mathrm{m}^{2}$ \\
\hline 132 & inverzijski & 66 & višinski & -1000 & I \\
\hline 123 & izredne poplave & 62 & redne poplave & -1000 & l \\
\hline 667 & & 333 & & -7000 & \\
\hline
\end{tabular}




\begin{tabular}{|c|c|c|c|c|}
\hline \multicolumn{3}{|c|}{ C) POVRŠINE S SADOVNJAKI } & \multirow{2}{*}{\multicolumn{2}{|c|}{$68 \%$ primerkov }} \\
\hline \multirow{2}{*}{$\begin{array}{c}\text { Geofaktor oz. } \\
\text { geoekološki dejavnik }\end{array}$} & \multirow{2}{*}{$\begin{array}{l}\text { Korel. } \\
\text { koeficient } \\
\quad \mathbf{K}\end{array}$} & \multirow{2}{*}{$\begin{array}{c}\text { Ponder } \\
(\mathbf{P}=\mathrm{K} / \\
\Sigma \mathrm{C} \\
\mathrm{x} 1000)\end{array}$} & & \\
\hline & & & $\begin{array}{l}\text { Št. točk } \\
\mathbf{T}=\mathrm{P}\end{array}$ & Meje razreda \\
\hline 1. Nadmorska višina & 0,23 & 64 & 64 & $430-560 m$ \\
\hline 2. Naklon & 0,61 & 169 & 169 & $<16^{\circ}$ \\
\hline 3. Tip prsti & 0,36 & 100 & 100 & l \\
\hline 4. Vod. razmere v prsti & 0,95 & 263 & 263 & norm, odtok \\
\hline 5. Osončenost & 0,64 & 177 & 177 & $>4300 \mathrm{MJ} / \mathrm{m} 2$ \\
\hline 6. Toplotni pas & 0,82 & 227 & 227 & termalni \\
\hline Vsota C ( $\Sigma C)$ & 3,61 & 1000 & 1000 & \\
\hline \multicolumn{5}{|c|}{ D) TRAVNIŠKE POVRŠINE } \\
\hline \multirow{2}{*}{$\begin{array}{c}\text { Geofaktor oz. geoeko- } \\
\text { loški dejavnik }\end{array}$} & \multirow{2}{*}{$\begin{array}{c}\text { Korel. koefici- } \\
\text { ent } \\
\text { K }\end{array}$} & \multirow{2}{*}{$\begin{array}{l}\text { Ponder } \\
(\mathbf{P}=\mathrm{K} / \\
\sum \mathrm{D} \\
\mathrm{x} 1000)\end{array}$} & \multicolumn{2}{|c|}{$\begin{array}{c}1 \\
68 \% \text { primerkov }\end{array}$} \\
\hline & & & $\begin{array}{c}\text { Št. točk } \\
\mathbf{T}=\mathrm{P}\end{array}$ & Meje razreda \\
\hline 1. Nadmorska višina & 0,57 & 113 & 113 & $<440 \mathrm{~m}$ \\
\hline 2. Naklon & 0,72 & 143 & 143 & $<12^{\circ}$ \\
\hline 3. Tip prsti & 0,45 & 89 & 89 & $5,8,9,11$ \\
\hline 4. Vod. razmere v prsti & 0,82 & 162 & 162 & norm, odtok \\
\hline 5. Osončenost & 0,61 & 121 & 121 & $>4100 \mathrm{MJ} / \mathrm{m} 2$ \\
\hline 6. Toplotni pas & 0,97 & 192 & 192 & termalni \\
\hline 7. Poplavne razmere & 0,91 & 180 & 180 & ni poplav \\
\hline Vsota D ( $\Sigma$ D) & 5,05 & 1000 & 1000 & \\
\hline
\end{tabular}

Po višinski razliki, ki smo jo ocenjevali le $\mathrm{v}$ primeru pozidave tal, smo površinsko enoto uvrstili v prvi kakovostni razred, če razlika do najbližjega dolinskega dna znaša manj kot $170 \mathrm{~m}$ in $\mathrm{v}$ drugi kakovostni razred, če znaša 170 do $300 \mathrm{~m}$. Tretji kakovostni razred pomeni razlika nad $300 \mathrm{~m}$. 
Fizičnogeografsko vrednotenje podeželskega prostora za kmetijstvo in pozidavo

\begin{tabular}{|c|c|c|c|c|c|}
\hline \multicolumn{6}{|c|}{ Kakovostni razred } \\
\hline \multicolumn{2}{|c|}{$\begin{array}{c}\mathbf{2} \\
27 \% \text { primerkov }\end{array}$} & \multicolumn{2}{|c|}{$\begin{array}{c}\mathbf{3} \\
5 \% \text { primerkov }\end{array}$} & \multicolumn{2}{|c|}{$\stackrel{4}{\mathbf{4}}$ abs. onemogočena raba } \\
\hline $\begin{array}{l}\text { Št. točk } \\
\mathbf{T}=2 / 3 \mathrm{P}\end{array}$ & Meje razreda & $\begin{array}{l}\text { Št. točk } \\
T=1 / 3 P\end{array}$ & Meje razreda & Št. točk & Meje razreda \\
\hline 42 & $\begin{array}{c}350-430 \text { in } \\
560-640\end{array}$ & 21 & $\begin{array}{l}<350 \mathrm{~m} \text { in } \\
640-800 \mathrm{~m}\end{array}$ & -1000 & $>800 \mathrm{~m}$ \\
\hline 113 & $16-20^{\circ}$ & 56 & $21-30^{\circ}$ & -1000 & $>30^{\circ}$ \\
\hline 66 & $2,4,5$ & 33 & $1,3,6,7,8,9,10,111$ & -1000 & l \\
\hline 175 & sušno ali vlažno & 88 & poplavne vode & -1000 & stoječa voda \\
\hline 118 & $4300-4000 \mathrm{MJ} / \mathrm{m} 2$ & 59 & $3999-3800 \mathrm{MJ} / \mathrm{m} 2$ & -1000 & $<3800 \mathrm{MJ} / \mathrm{m} 2$ \\
\hline 151 & inverzijski & 76 & višinski & -1000 & / \\
\hline 667 & & 333 & & -6000 & \\
\hline \multicolumn{6}{|c|}{ Kakovostni razred } \\
\hline \multicolumn{2}{|c|}{$\begin{array}{c}\mathbf{2} \\
27 \% \text { primerkov }\end{array}$} & \multicolumn{2}{|c|}{$\begin{array}{c}\mathbf{3} \\
5 \% \text { primerkov }\end{array}$} & \multicolumn{2}{|c|}{$\begin{array}{c}\mathbf{4} \\
\text { abs. onemogočena raba }\end{array}$} \\
\hline $\begin{array}{l}\text { Št. točk } \\
\mathbf{T}=2 / 3 \mathrm{P}\end{array}$ & Meje razreda & $\begin{array}{l}\text { Št. točk } \\
\mathbf{T}=1 / 3 \mathrm{P}\end{array}$ & Meje razreda & Št. točk & Meje razreda \\
\hline 75 & $440-650 m$ & 38 & $>650 \mathrm{~m}$ & -1000 & l \\
\hline 95 & $12-17^{\circ}$ & 48 & $18-30^{\circ}$ & -1000 & $>30^{\circ}$ \\
\hline 59 & $2,3,4,6$ & 30 & $1,7,10$ & -1000 & l \\
\hline 108 & sušno ali vlažno & 54 & poplavne vode & -1000 & stoječa voda \\
\hline 81 & $4100-3600 \mathrm{MJ} / \mathrm{m} 2$ & 40 & $<3600 \mathrm{MJ} / \mathrm{m} 2$ & -1000 & l \\
\hline 128 & inverzijski & 64 & višinski & -1000 & l \\
\hline 120 & izredne poplave & 60 & redne poplave & -1000 & l \\
\hline 667 & & 333 & & -7000 & \\
\hline
\end{tabular}

Korelacijski koeficient 0.8306 pove, da je višinska razlika pri pozidavi zelo pomemben dejavnik.

Glede osončenosti smo enote uvrstili v prvi razred, če v enem letu prejmejo naslednje količine sončne energije: pri pozidavi nad $4100 \mathrm{MJ} / \mathrm{m}^{2}$, pri 
ornih površinah nad $4200 \mathrm{MJ} / \mathrm{m}^{2}$, pri sadovnjakih nad $4300 \mathrm{MJ} / \mathrm{m}^{2}$, pri travnikih nad $4100 \mathrm{MJ} / \mathrm{m}^{2}$. Drugi razred predstavljajo pri pozidavi enote, katerih letna vsota sončne energije znaša med 3600 in 4100, pri njivah med 3900 in 4200, pri sadovnjakih med 4000 in 4300 in pri travnikih med 3600 in $4100 \mathrm{MJ} / \mathrm{m}^{2}$. V tretji razred spadajo površine, ki v primeru pozidave in travnikov prejmejo pod $3600 \mathrm{MJ} / \mathrm{m}^{2}$, pri njivah 3100 do $3899 \mathrm{MJ} / \mathrm{m}^{2}$, pri sadovnjakih pa 3800 do $3999 \mathrm{MJ} / \mathrm{m}^{2}$. Četrti razred smo uvedli le pri ornih površinah $\left(\operatorname{pod} 3100 \mathrm{MJ} / \mathrm{m}^{2}\right)$ in pri sadovnjakih $\left(\operatorname{pod} 3800 \mathrm{MJ} / \mathrm{m}^{2}\right)$.

Korelacije kažejo, da je pomen osončenosti podoben pri izbiri površin za pozidavo (0.6492), za sadovnjake (0.6367), in za travnike (0.6065), nekaj manjši pa v primeru njiv (0.5425).

Glede na toplotni pas smo pri vseh tipih rabe (pri pozidavi, njivah, sadovnjakih in travnikih) vzeli kot prvi razred termalni pas, drugi razred inverzijski pas in kot tretji razred višinski pas.

Pozidane površine, njive in travniki so daleč najpogostejši v inverzijskem pasu (korelacije $0.9666,0.9705,0.9657$ ), pri sadovnjakih pa korelacija znaša 0.8179 .

Povezavo s tipom prsti smo ugotavljali pri vseh vrstah rabe tal, razen pri pozidavi. Noben tip prsti si glede primernosti za njive ali sadovnjake ni zaslužil prvega kakovostnega razreda. $Z$ vidika travništva pa smo ga na podlagi indeksov koncentracije pripisali evtričnim in distričnim rjavim prstem in rankerjem ter globoko in srednje globoko oglejenim nekarbonatnim obrečnim prstem. V drugem kakovostnem razredu so $\mathrm{v}$ primeru njivskih površin distrične in evtrične rjave prsti in rankerji, globoko oglejene nekarbonatne obrečne prsti in močan in srednje močan evtrični mineralni hipoglej, v primeru sadovnjakov pa rjave pokarbonatne prsti in rendzine, distrične rjave prsti z rankerji. Rjave pokarbonatne prsti in distrične rjave prsti z rankerji v različnih razmerjih pomenijo drugi razred tudi pri travnikih. Tretjerazredne so za njive rendzine in rjave pokarbonatne prsti z rendzino, distrične rjave prsti in rankerji in srednje globoko oglejene nekarbonatne obrečne prsti, za sadovnjake pa vse pokarbonatne prati z rendzinami, vse oglejene prsti in hipogleji. Za travnike so najmanj izkoriščene rendzine in rjave pokarbonatne prsti, evtrične rjave prsti in močan evtrični mineralni hipoglej. Prsti v podolju so močno antropogenizirane. Povezave rabe tal s tipom prsti zato niso zelo močne (korelacija 0.3737 pri njivah, 0.3603 pri sadovnjakih in 0.4526 pri travnikih).

Glede na poplavni svet smo območje ocenili kot prvorazredno za pozidavo, orne površine in za travnike, če ga ne ogrožajo poplave. Drugega razreda ni, tretjerazreden pa je $\mathrm{v}$ primeru njiv in travnikov svet, poplavljen ob rednih poplavah. Za pozidavo so merila strožja: $z$ možnostjo poplav se območje uvršča v četrti razred. Korelacija pri njivah znaša 0.9104 , podobno je pri travnikih (0.9106), pri pozidanih površinah pa 0.8720 . 
Korelacijski koeficienti kažejo stopnjo povezanosti rabe tal s posameznimi geoekološkimi dejavniki. So podlaga za določitev teže teh dejavnikov v primeru posameznega tipa rabe tal ali za ponderiranje. Če geoekološke dejavnike rangiramo po ponderjih, si v primeru občine Moravče pri pozidavi po pomenu sledijo: nosilnost tal (ponder 178), toplotni pas (174), poplavne razmere (156), višinska razlika (149), naklon (135), osončenost (117), nadmorska višina (90). Z vidika ornih površin je zaporedje naslednje: toplotni pas (198), poplavne razmere (185), vodne razmere v prsti (185), naklon (151), nadmorska višina (96) in tip prsti (75). Vpliv geofaktorjev na razmestitev sadnega drevja kažejo ponderji: vodne razmere v prsti (263), toplotni pas (227), osončenost (177), naklon (169), tip prsti (100), nadmorska višina (64). Za travnike pa velja zaporedje: toplotni pas (192), poplavne razmere (180), vodne razmere v prsti (162), naklon (143), osončenost (121), nadmorska višina (113) in tip prsti (89).

Zdaj za izbrane fizičnogeografske dejavnike izdelamo nove karte, od katerih ima vsaka štiri kakovostne razrede. Prvemu razredu pripišemo število točk, ki je enako celotni vrednosti ponderja. Drugemu razredu pripade število točk, ki je enako dvema tretjinama vrednosti ponderja, tretjemu pa toliko točk kot je tretjina vrednosti ponderja. Pripadnost četrtemu razredu pomeni pripis 1000 negativnih točk. S tem zagotovo dosežemo izločitev območja, ki je glede enega samega ali pa več kriterijev pripadlo četrtemu, najslabšemu kakovostnemu razredu.

Na koncu prekrijemo vseh sedem oziroma šest kart in jih seštejemo. Število plasti je odvisno od tega, koliko kriterijev smo pri posamezni rabi upoštevali. Če je neka celica po vseh kriterijih pripadla 1. kakovostnemu razredu lahko zbere največ 1000 točk. Če je po enem ali več kriterijih v četrtem razredu, ima za vsak četrti razred 1000 negativnih točk. Na podlagi seštevka točk jo uvrstimo v enega od novih osmih kakovostnih razredov:

\begin{tabular}{|l|c|c|c|c|c|c|c|c|}
\hline \multicolumn{7}{|c|}{ Kakovostni razred posameznega tipa rabe tal in pripadajoče število točk } \\
\hline Razred & 1 & 2 & 3 & 4 & 5 & 6 & 7 & 8 \\
\hline Št. točk & $951)-1000$ & $90(1-949$ & $80(1-899$ & $70(1-799$ & $60(1-699$ & $50(1-599$ & $1-<.99$ & 0 in manj \\
\hline
\end{tabular}

Na karti označimo razrede 1 do 4 z rdečo barvo, ki je tem intenzivnejša, čim boljši je kakovostni razred, razrede 5 do 7 z modro barvo, katere intenzivnost raste $\mathrm{z}$ upadanjem števila točk, 8. kakovostni razred pa pobarvamo rumeno. Rumena barva označuje za določeno rabo absolutno neprimerne površine (celice s seštevkom 0 ali s 1000 do 7000 negativnimi točkami). Z ustreznimi ukrepi (na primer melioracijami v primeru poplavnega sveta) lahko dosežemo, da te površine naknadno postanejo bolj ali manj primerne za neko intenzivnejšo rabo. 
$\mathrm{Na}$ osnovi opisanih kriterijev smo izdelali štiri ločene sintetske karte, ki so vmesni rezultat:

- karto primernosti površin za njive,

- karto primernosti površin za sadovnjake,

- karto primernosti površin za travnike,

- karto primernosti površin za pozidavo.

Za posamezno rabo smo izdelali po dve inačici kart. Pri prvi ugotavljamo primernost vseh površin ne glede na obstoječo rabo, dopuščamo torej krčenje gozda, pri drugi pa smo gozdne in že pozidane površine kot možni prostor za neko drugo rabo izločili. Če želimo najprej izkoristiti negozdne površine, se obseg površin, primernih za določeno rabo, močno skrči; zanima nas predvsem druga karta. Šele v skrajnem primeru lahko predlagamo tudi pridobitev površin za neko rabo na račun gozda.

Ko določimo še hierarhično lestvico posameznih tipov rabe tal in prekrijemo delne sintetske karte, dobimo sintetsko karto najprimernejše rabe tal oziroma karto optimalne rabe tal. Ta nam je nepogrešljivo vodilo pri regionalnem planiranju. Kot prednostno izberemo tisto rabo, ki ima v določeni celici najvišje število točk oziroma je v višjem kakovostnem razredu. Če pa dve rabi pripadata istemu kakovostnemu razredu, upoštevamo hierarhijo: prednost smo dali njivam, sledijo vinogradi, sadovnjaki, pozidava, travniki. Najpogosteje se prekrivajo najprimernejše površine za njive in za pozidavo. Zdaj lahko izločimo najbolj nesmiselno obstoječo rabo in pokažemo za določeno rabo še neizkoriščene površine.

Izračunani ponderji se nanašajo konkretno na določeno regijo, ker so bili izračunani na podlagi tamkajšnje rabe tal. Zato jih ne moremo sprejeti kot splošno veljavne. Kriteriji so torej odvisni od nivoja, na katerem izdelujemo regionalni načrt in jih izbiramo ter določamo ponderje vedno sproti. Podobno je tudi z mejami kakovostnih razredov. Izkazalo se je, da je za obdelavo zaradi svoje velikosti med najprimernejšimi enotami občina.

Primernost površin za posamezne tipe rabe tal v občini Moravče - osem kakovostnih razredov

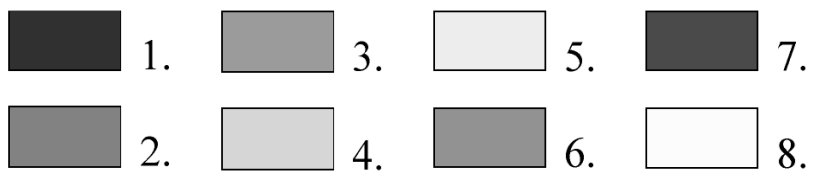


Slika 2: Primernost površin za njive

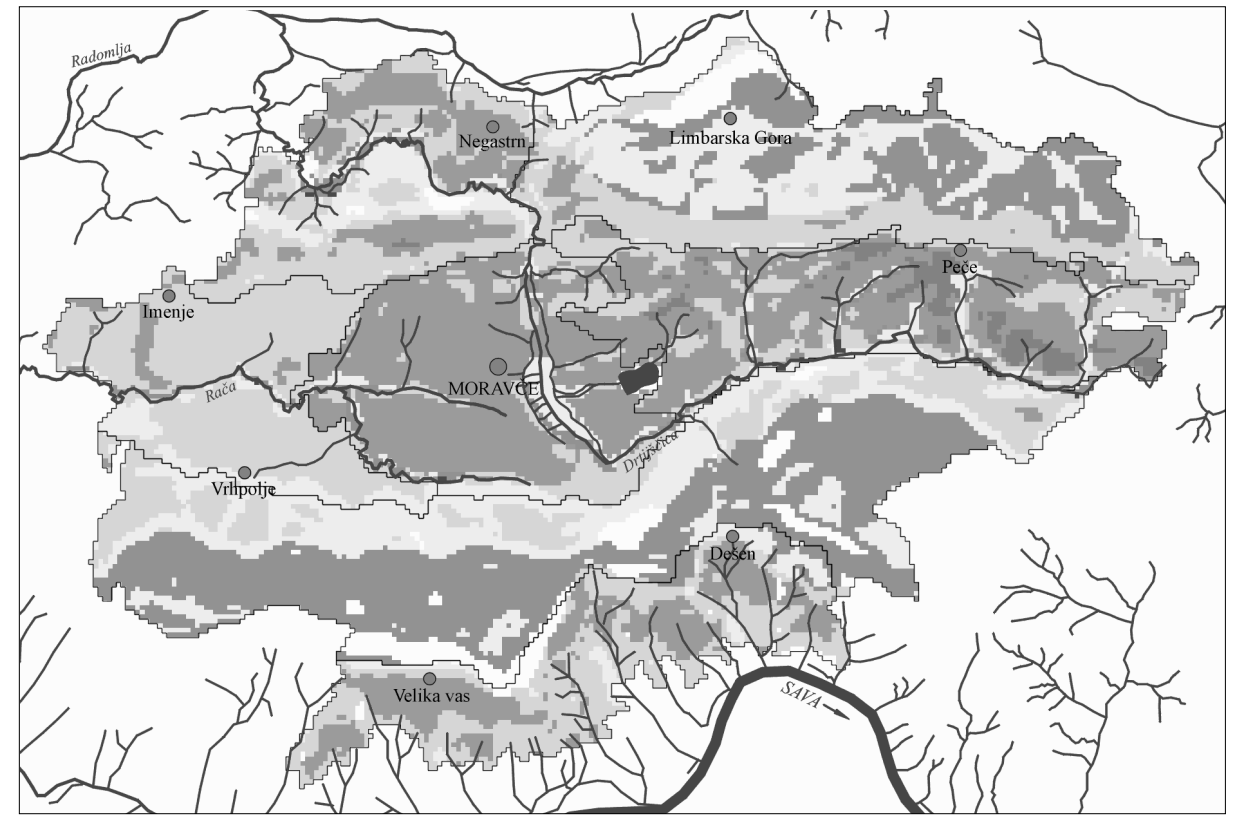

Slika 3: Primernost površin za njive - gozd izločen

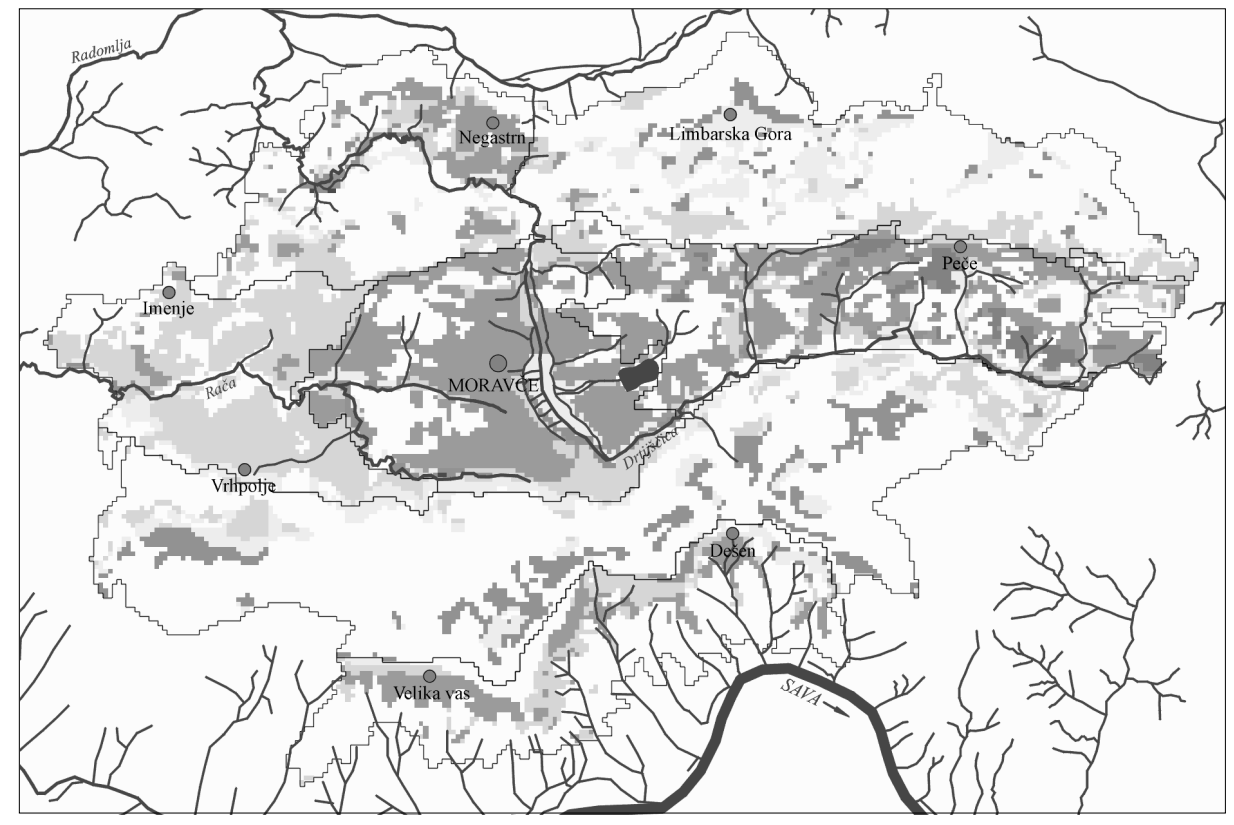


Slika 4: Primernost površin za sadovnjake

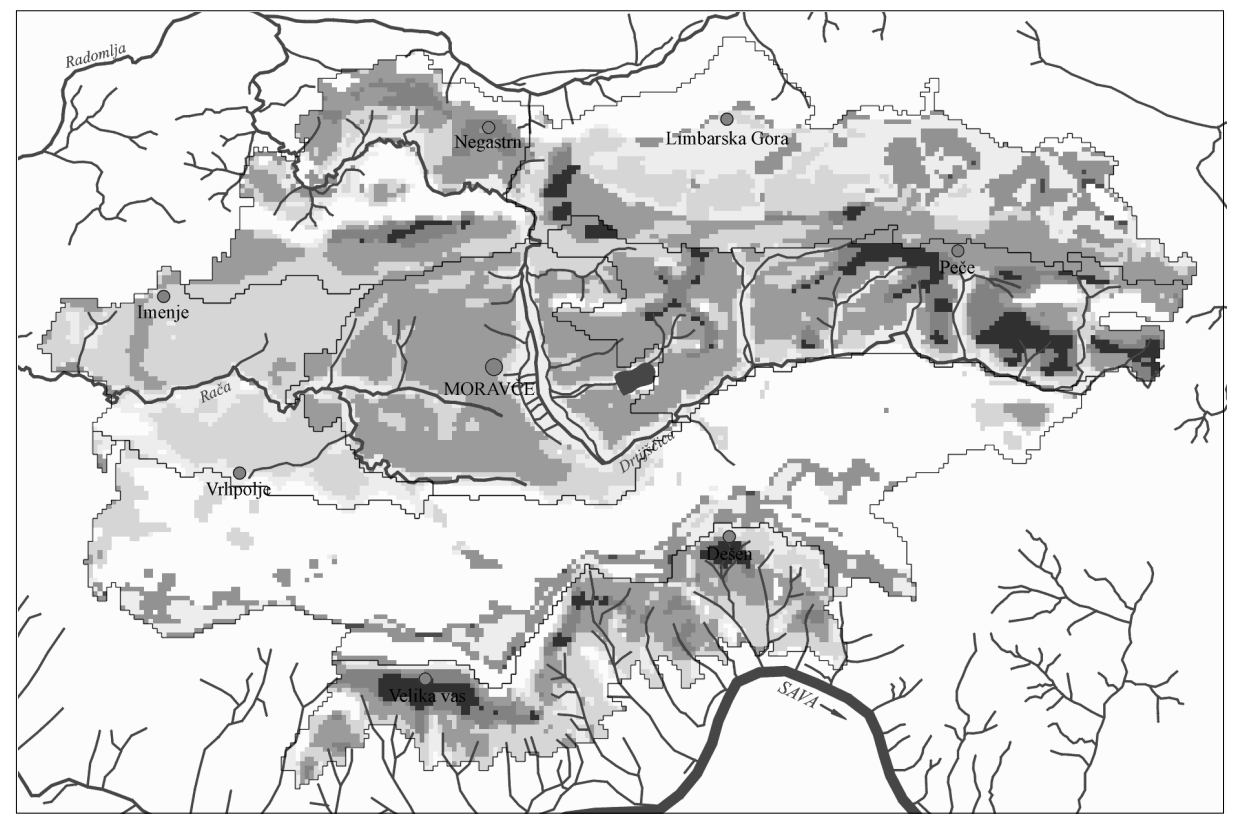

Slika 5: Primernost površin za sadovnjake-gozd izločen

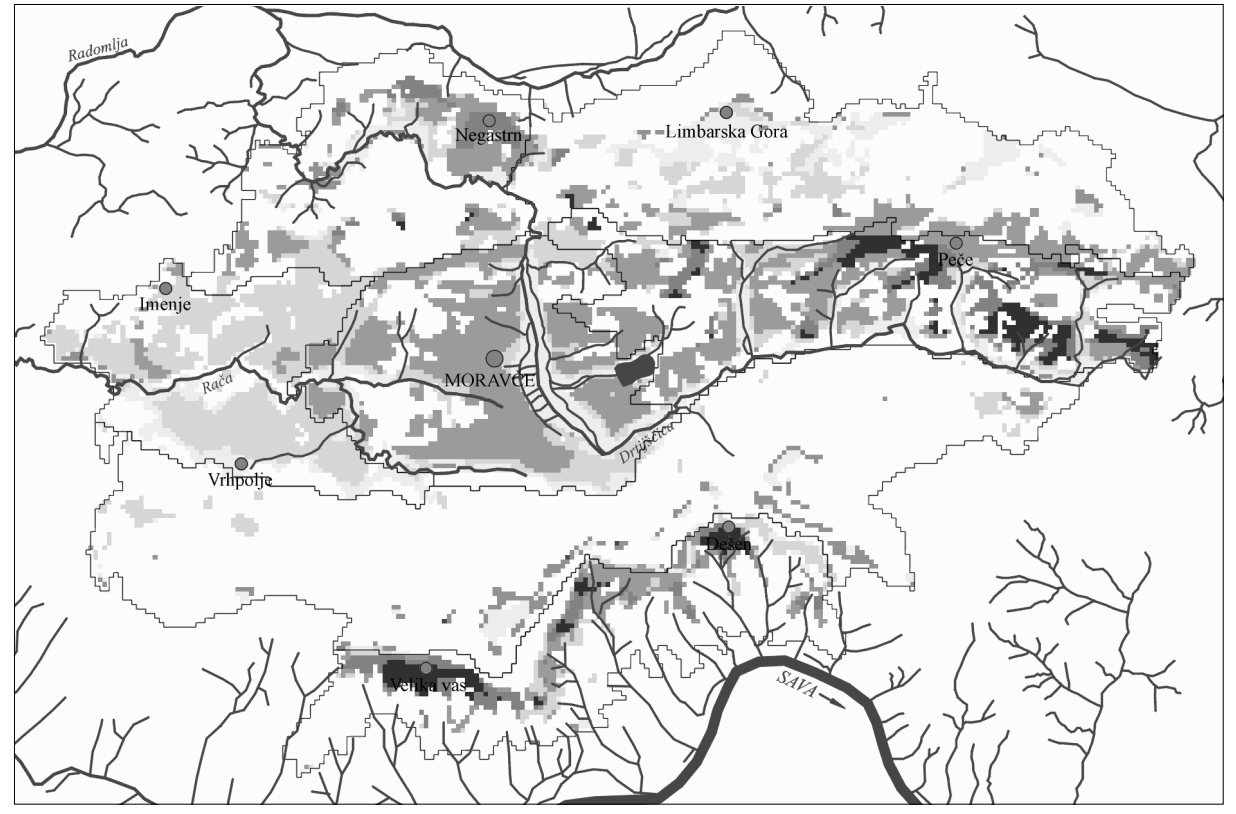


Slika 6:Primernost površin za travnike

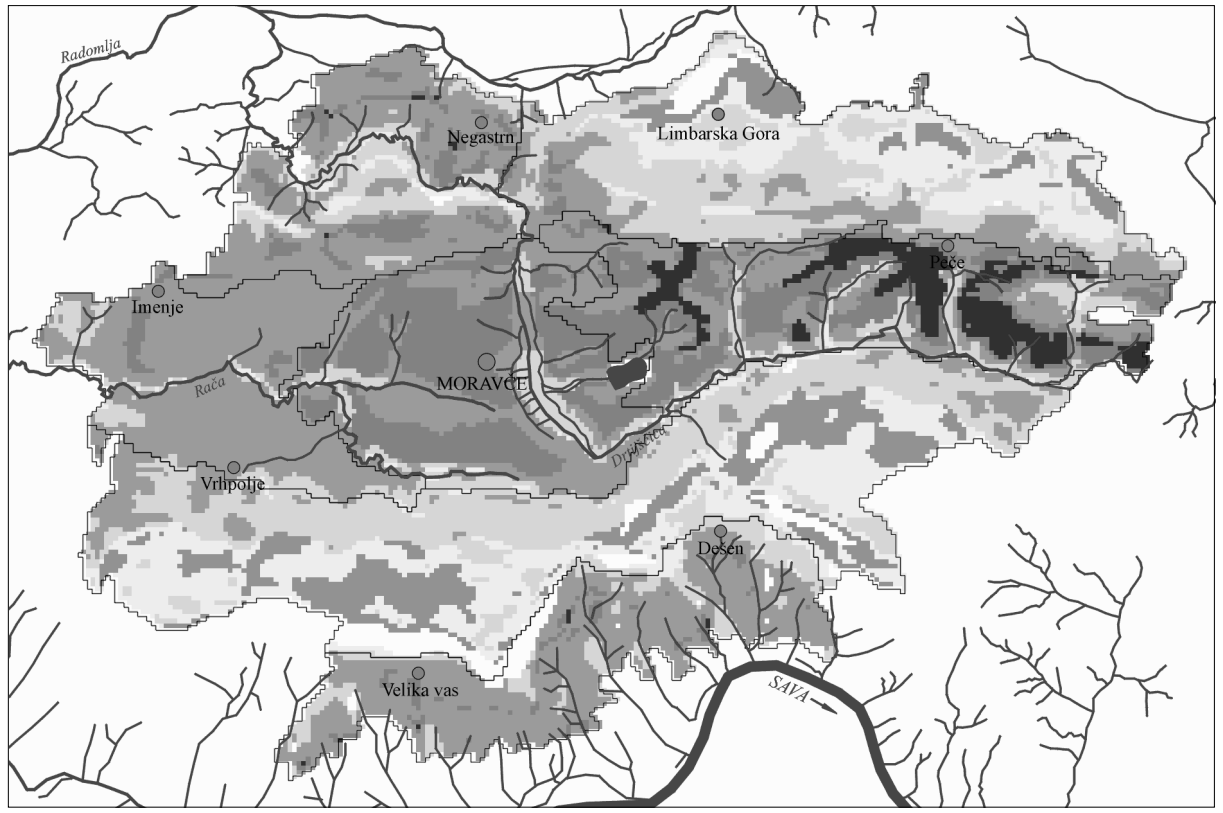

Slika 7: Primernost površin za travnike - gozd izločen

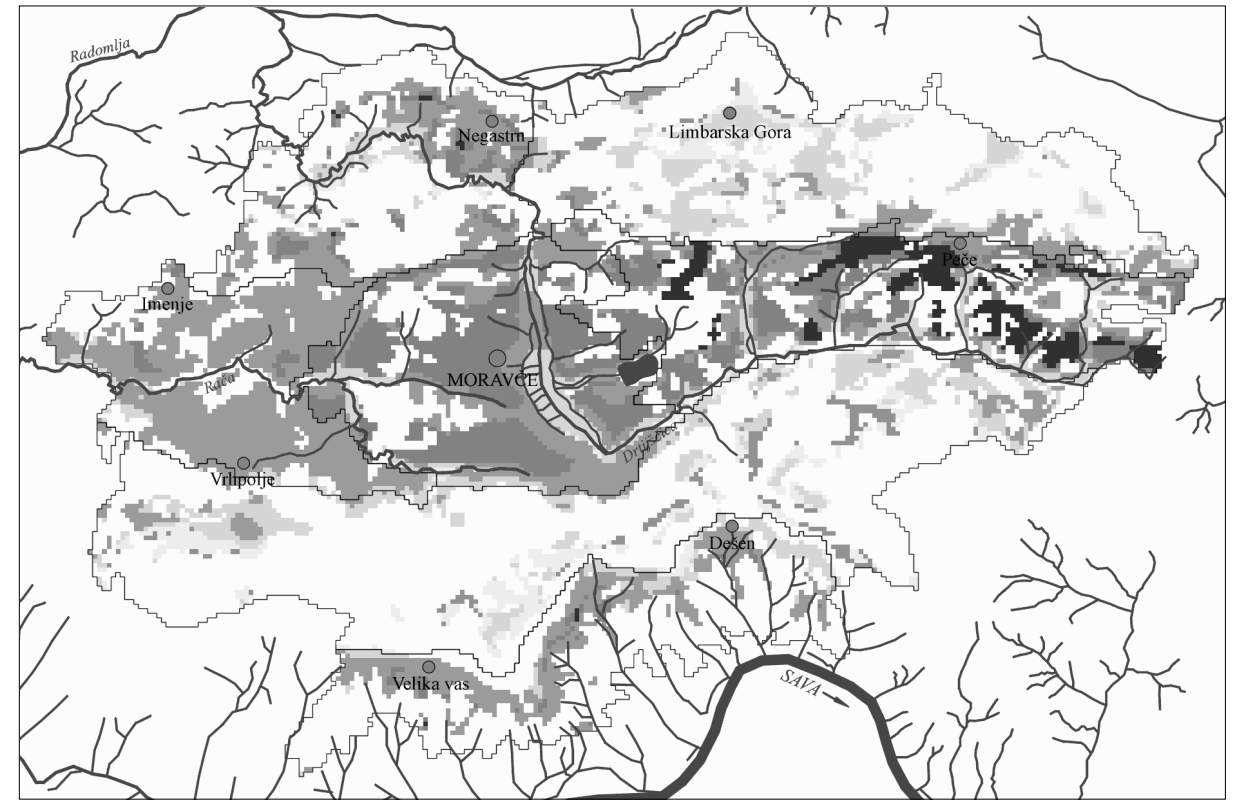


Slika 8: Primernost površin za pozidavo

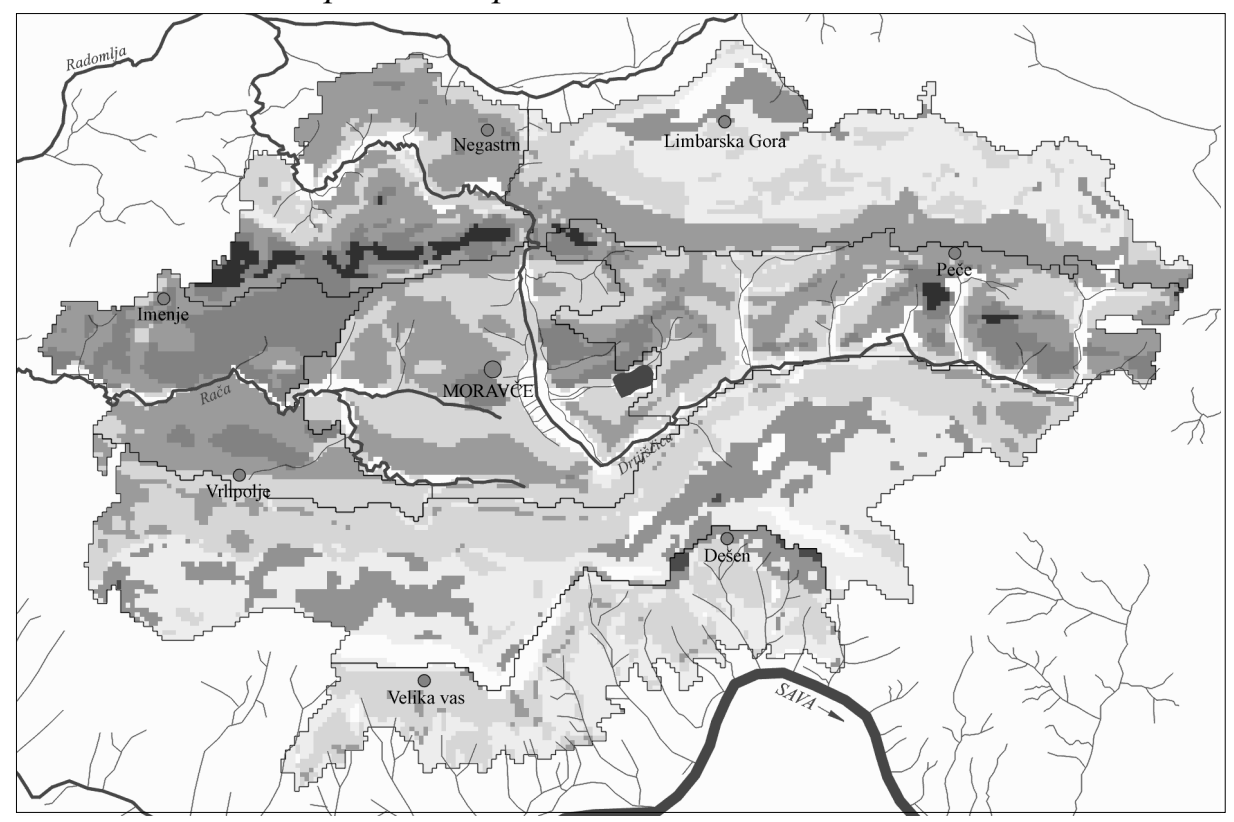

Slika 9: Primernost površin za pozidavo - gozd izločen

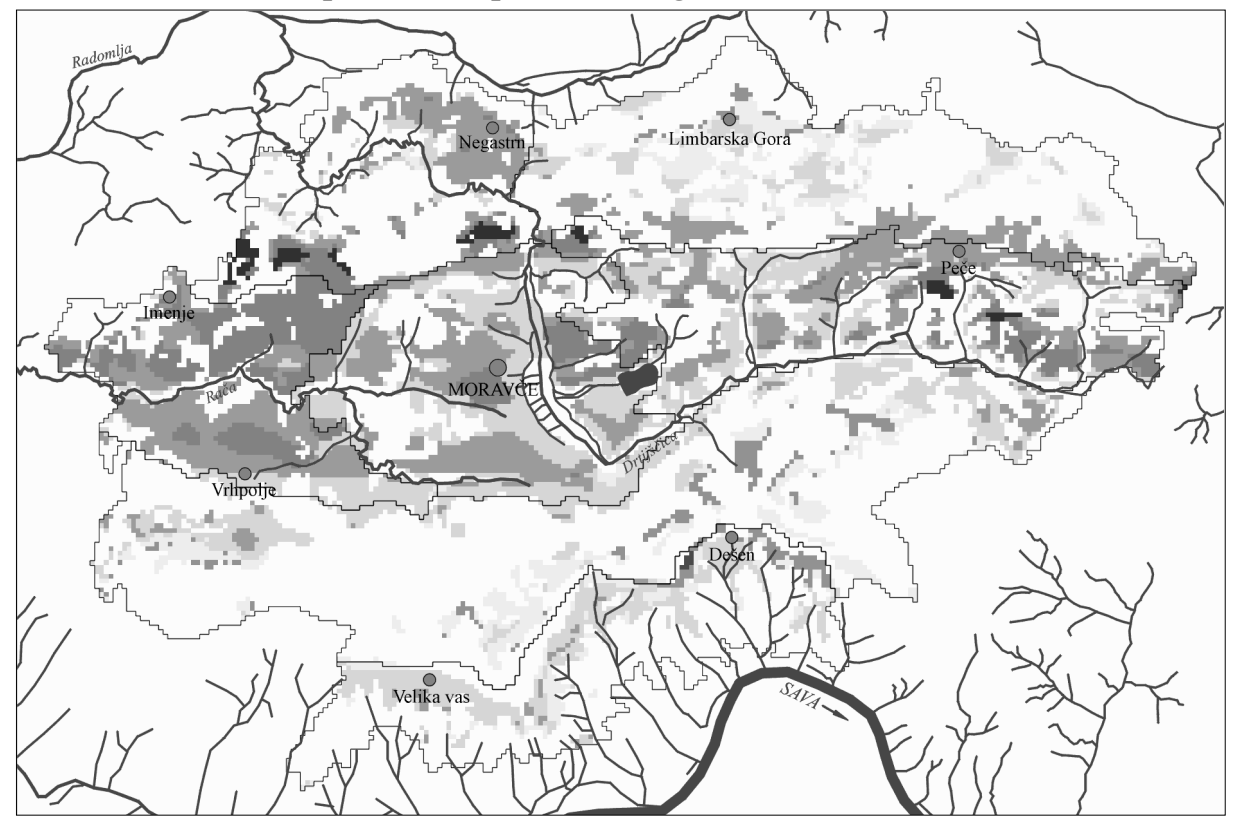


Slika 10: Občina Moravče - Obstoječa raba tal

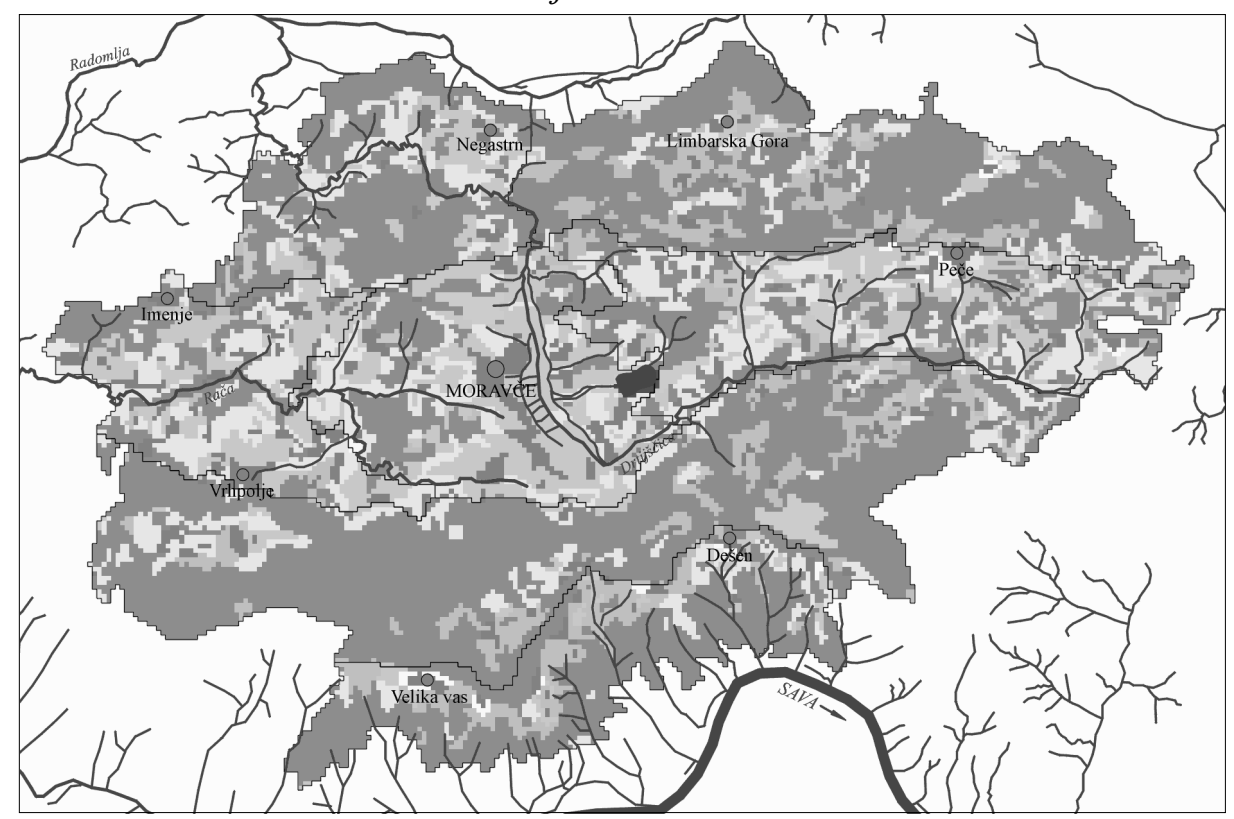

pozidane površine

njive

sadovnjaki

travniki

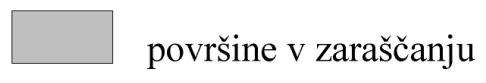

gozd

nerodovitne površine

vodne površine 
Slika 11: Občina Moravče - Optimalna raba tal (upoštevane so vse površine)
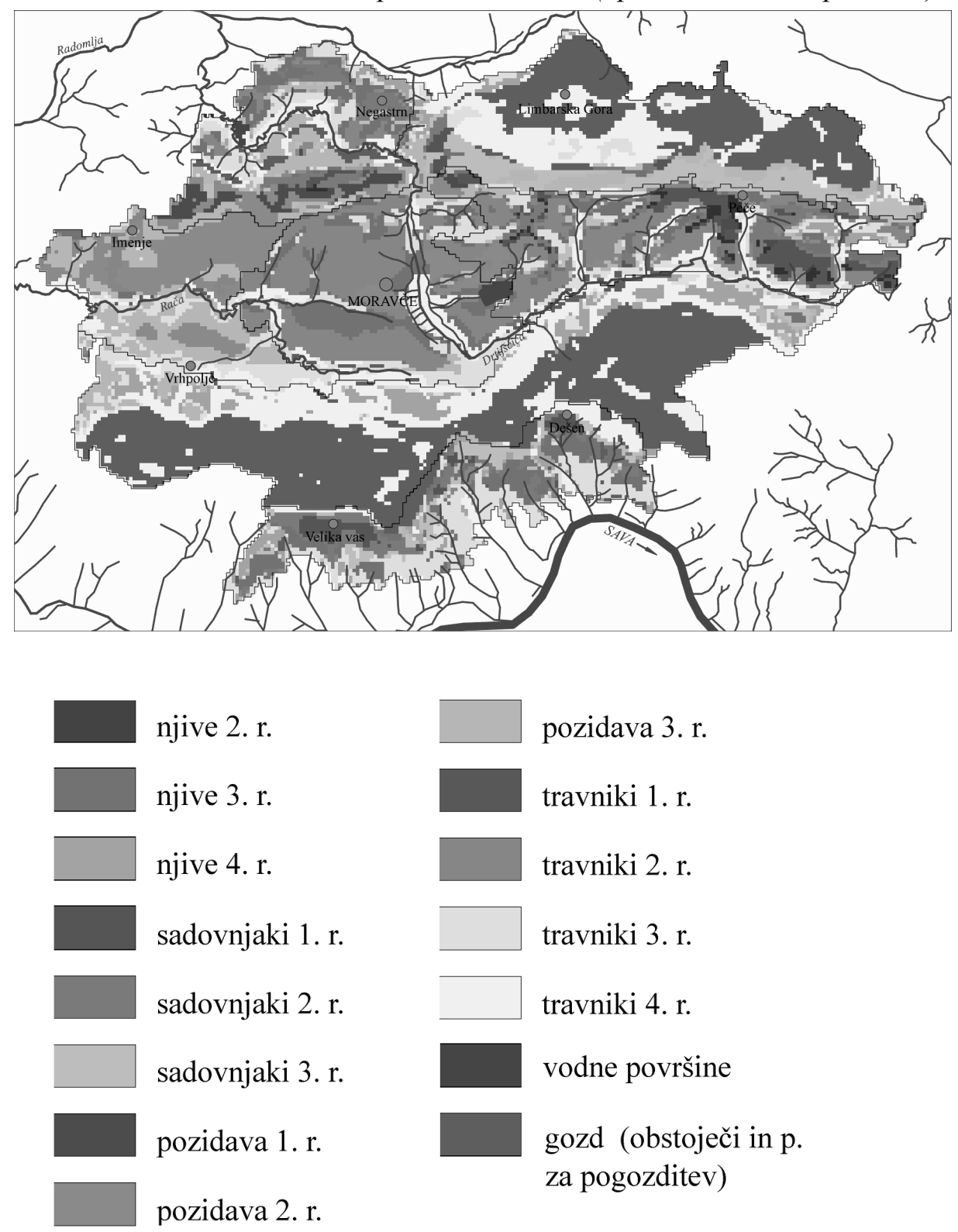

njive $2 . r$.

pozidava 3. $\mathrm{r}$.

njive $3 . r$.

travniki 1.r.

njive 4. r.

travniki 2. r.

sadovnjaki 1.r.

travniki 3. r.

sadovnjaki 2. r.

travniki 4. r.

sadovnjaki 3. r.

vodne površine

pozidava 1 . r.

gozd (obstoječi in p.

pozidava 2. r. 
Slika 12: Občina Moravče - Optimalna raba tal (gozdne in pozidane površine so izločene)
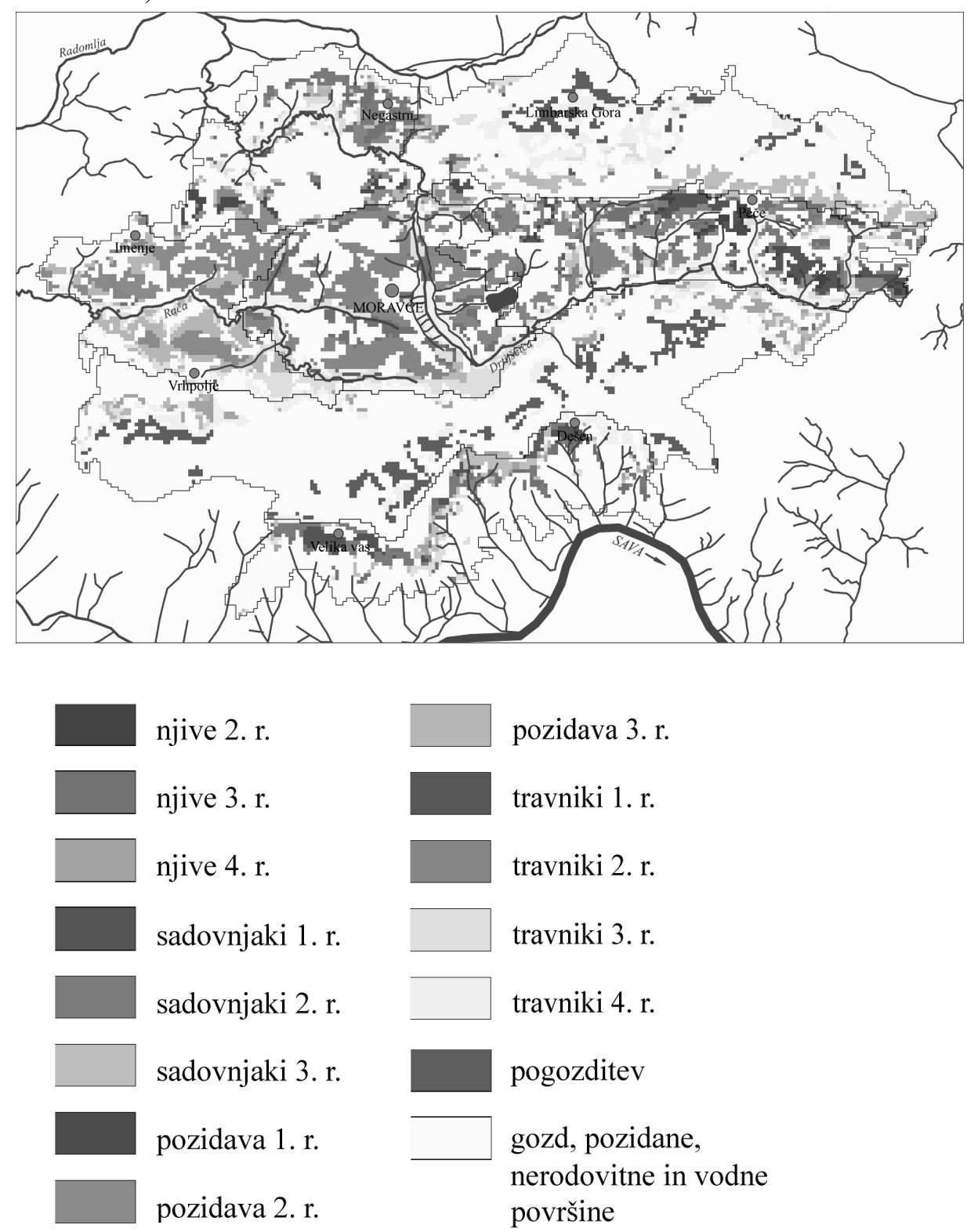

njive 2. $r$.

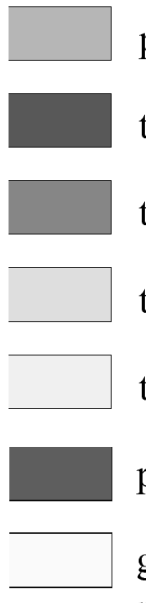

pozidava 3. r.

njive 3. $\mathrm{r}$.

travniki 1. r.

njive 4. $\mathrm{r}$.

travniki 2. r.

sadovnjaki 1.r.

travniki 3. r.

sadovnjaki 2. r.

travniki 4. r.

sadovnjaki 3. r.

pogozditev

pozidava 1. r.

gozd, pozidane,

pozidava 2. r.

nerodovitne in vodne površine 
Slaba stran metode je dolgotrajnost postopka ter odvisnost od obstoječih strokovnih obdelav in njihove kakovosti. Idealno bi bilo, da bi prva faza obdelav oziroma analitsko delo nastalo kot rezultat interdisciplinarnega dela. Odprt ostaja še drug problem: za dokončno odločanje o optimalni rabi tal bi morali upoštevati še okoljevarstvene, socialne, ekonomske in morda še druge vidike, kar pa zahteva pritegnitev novih strokovnjakov.

\section{Viri:}

Blejec, M., 1976. Statistične metode za ekonomiste. Ljubljana.

Digitalni model reliefa 25 × 25 m. Geodetska uprava Republike Slovenije.

Gabrovec, M., 1996. Sončno obsevanje v reliefno razgibani Sloveniji. Geografski zbornik 36, str. 47-68. Ljubljana.

Goldman, S. J., Jackson, K., Bursztynsky, T. A., 1986. Erosion and sediment control handbook. New York.

Hrvatin, M., Perko, D., Topole, M., 1999. Občina Moravče, Geografske podlage za ugotavljanje optimalne rabe tal. Elaborat na Geografskem inštitutu A. Melika, ZRC SAZU. Ljubljana.

Letalski posnetki občine Moravče 21. 7. 1998 v M 1: 17.500, kontaktne kopije. Geodetski zavod Slovenije. Ljubljana.

Morgan, R. P. C., 1980. Soil erosion, Topics in applied Geography. New York.

Osnovna geološka karta SFRJ 1 : 100.000, list Ljubljana. Geološki zavod Ljubljana. Ljubljana, 1978.

Osnovna pedološka karta SFRJ v m $1: 50.000$, list Ljubljana. Katedra za pedologijo, prehrano rastlin in ekologijo, Biotehniška fakulteta v Lju-bljani. Ljubljana, 1985.

Seizmična karta Slovenije. Zavod za raziskavo materiala in konstrukcij. Ljubljana, 1982.

Seuffert, O., 1993. Die Bodenerosion als ökologischer Faktor und als wissenschaftliches Problem. Petermanns Geographische Mitteilungen, str. 259 274. Gotha.

Topografske karte VGI Beograd, merilo $1: 25.000$. Sekcije Nevlje, Zgornji Tuhinj, Dolsko, Litija.

Topole, M., 1999. Geografsko preučevanje občine Moravče. Vrednotenje zemljišč za različne tipe rabe tal. Elaborat na Geografskem inštitutu A. Melika, ZRC SAZU. Ljubljana.

Topole, M., 1996. Šentruperska mikroregija, Geoekološke razmere v pokrajini. Šentruperska mikroregija, Razvojni projekt CRPOV za naselje Šentrupert z okolico. Šentrupert. 
Topole, M., 1998. Mirnska dolina, Regionalna geografija porečja Mirne na Dolenjskem. Ljubljana.

Vegetacijska karta Slovenije v M 1:50.000 iz let 1973-1974, lista Ljubljana in Celje. Rokopisna karta Biološkega inštituta Jovana Hadžija ZRC SAZU. Ljubljana.

\section{EVALUATION OF SPACE FOR VARIOUS TYPES OF LAND USE}

\section{Summary}

The paper presents a method for evaluating rural space that with further refinement can be used in the integral planning of land use. The method was applied in the case of two municipalities within the framework of the Celostno urejanje podeželja in obnova vasi ("Integral Arrangement of the Countryside and Village Restoration") project and can be used if larger and medium scale $(1: 10,000-1: 50,000)$ basic maps of natural elements are available for a landscape unit. Such maps provide fundamental information about an area's geography and its regionalization.

As a basis we employ a digital relief model $(50 \times 50 \mathrm{~m}$ or $25 \times 25 \mathrm{~m})$ to acquire a grid of several thousand small squares for which numerous mathematic and statistical calculations can be made. In the first phase, the primary natural and geographical factors are analyzed: surface (rock composition, altitude, slope, ground stability or seismic velocities, type of surface), waters, groundwater conditions, flood conditions, climate (temperature, precipitation, exposition, insolation, heat belts), soil, vulnerability to erosion, and vegetation. Among sociogeographical factors we consider population and settlement with special attention paid to the analysis of existing land use. This includes built-up areas, vineyards, cultivated fields, orchards, meadows, overgrown areas, forests, barren, and water surfaces. The current situation is determined from 1:17,500-scale aerial photographs, and a control field survey is done as well. We determine the interdependence and effects of these factors and the typical occurrence of individual types of land use. The first phase concludes with a regionalization that is the first synthesis.

In the second phase, we evaluate the areas for different types of land use and recommend the most appropriate use, the criteria being selected natural and geographical elements. We calculate correlation coefficients the show the degree of connection between these elements and various types of land use. On this basis we determine "ponders," the weighting for each individual type 
of land use. The intermediate results are maps that show the suitability of areas for cultivated fields, vineyards, orchards, meadows, and building. Having determined a hierarchical scale of individual types of use and overlapped partial synthetic maps, we acquire a map of the most appropriate land use or a map of optimal land use. Such maps are indispensable for regional planning. We can exclude the most unsuitable uses and indicate a particular use for unexploited areas. In extreme cases, we recommend acquiring areas for some uses at the expense of forest.

The calculated limits of quality classes and ponders apply specifically to a certain region and cannot be accepted as universally valid. Due to its size, the municipality unit proved to be one of the most suitable units to handle.

The weakness of this method is the long procedure, which also depends on existing professional work and its quality. It would be ideal if the first phase were the result of interdisciplinary work. A further problem exists: to ultimately determine the optimal land use, we must also consider environmental protection, social, economic, and other viewpoints, which requires involving new professional specialists from these fields in the work. 